Paediatr Croat. 2016;60:31-5 PRIKAZ BOLESNIKA / CASE REPORT www.paedcro.com http://dx.doi.org/10.13112/PC.2016.6

\title{
Subacute metacarpal osteomyelitis in a child
}

\author{
Hamdi Kaziz, Thabet Mouelhi, Walid Osman, Mohamed Amine Triki, \\ Nader Naouar, Mohamed Laziz Ben Ayeche
}

Subacute osteomyelitis is a rare affection. Clinical presentation is often unclear and can lead to delay in diagnosis. As a matter of fact, subacute metacarpal osteomyelitis is usually missed at first, so that some complications may occur, e.g., brachymetacarpia or loss of motion. We report on a 10-year-old boy with subacute metaphyseal osteomyelitis of the second right metacarpal bone. Radiological features can mimic various benign or malignant bone tumors and non-pyogenic infections. Histologic confirmation is necessary to avoid delay in diagnosis. Treatment was based on antibiotics and surgical debridement. No infectious agent was found on bacteriologic testing. At 1-year follow up, no complications were reported and the finger showed normal range of motion. X-ray views showed bone reconstruction with fibrosis of the ulnar part of the metaphysis, without length discrepancy.

Keywords: subacute; metacarpal; osteomyelitis; treatment; complications

\section{INTRODUCTION}

Subacute metacarpal osteomyelitis in children is a rare affection. Despite the acute form tropism to the long bone metaphysis, especially in lower limbs, the subacute form does not follow this concept. It is characterized by particular involvement pathology.

The aim of our case report is to reveal the main features of subacute metacarpal osteomyelitis in children, and to review treatment options and outcome.

\section{CASE REPORT}

We report on a 10-year-old boy admitted to our department for pain and stiffness of the second metacarpo-phalangeal joint of his right hand that had started two months before. No fever or infectious signs were found. Physical examination revealed a little reduction of motion in the metacarpo-phalangeal joint without swelling or signs of injury (Figure 1). Temperature was normal. Laboratory findings were negative. X-rays showed a well defined radiolucent defect in the ulnar part of the metaphysis of the second metacarpal bone, associated with sclerosis in the radial part (Figure 2). Scan tomography found a radiolucent defect of the metaphyseal part of the carpal bone (Figure 3) suggesting an infectious disease. The diagnosis of subacute osteo-

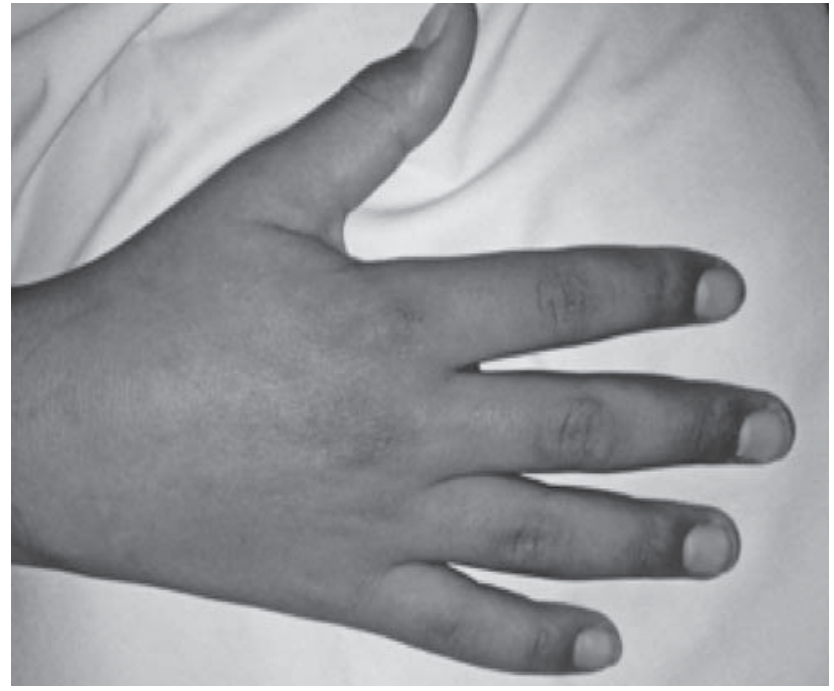

FIGURE 1. Dorsal view of the hand before the intervention.

myelitis was suspected. Hence, intravenous empirical antibiotic therapy based on oxacillin and gentamicin was start* Department of Orthopedics, Sahloul University Hospital Sousse Tunisia,
4045 Sahloul City Sousse Republic of Tunisia

\section{Correspondence to:}

Hamdi Kaziz, MD; 57 Salem Gardabbou Street; 5020 Jemmel Tunisia; Tunis; e-mail: hamdi.kaziz@yahoo.fr; hamdi.kaziz@gmail.com

Primljeno/Received: 30. 5. 2015., Prihvaćeno/Accepted:25. 2. 2016. 


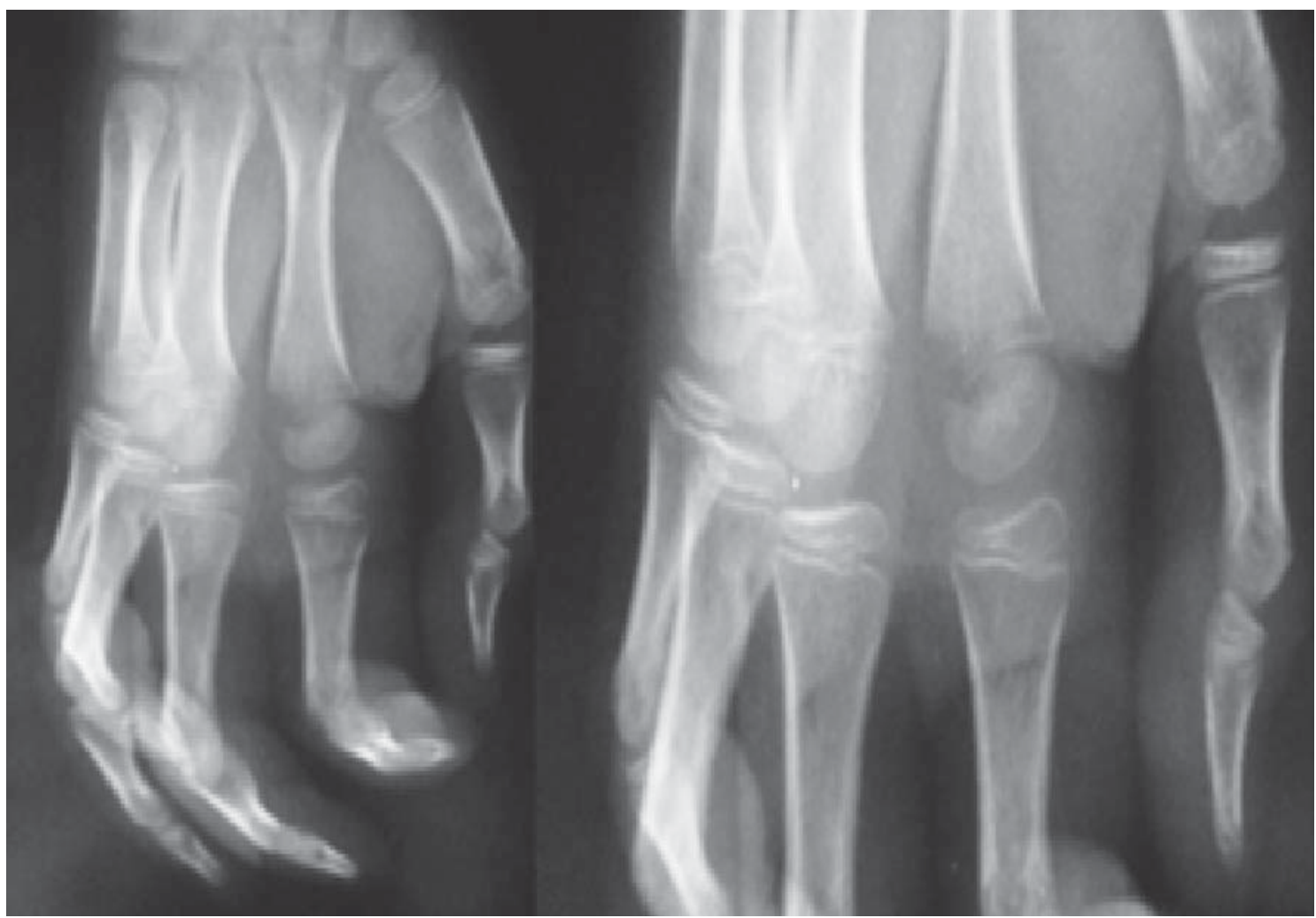

FIGURE 2. X-rays of the right hand revealing a bone defect on the radial part the metaphysis of the second metacarpal bone.

ed at daily doses of $1500 \mathrm{mg}$ and $80 \mathrm{mg}$, respectively. Unfortunately, clinical evolution, after seven days of antibiotic therapy, was unfavorable, with the same stiffness and pain. As a matter of fact, surgical treatment is advocated and a dorsal approach to the joint was used. Operative exploration found destruction of both the bone and the metaphyseal cartilage by local reaction associated with fibrosis and membranous tissues formations without purulent aspect. Surgical debridement of the infected site was undertaken and the hand was immobilized with a plaster splint for three weeks. Intravenous antibiotics were continued for one week until the results of histologic examinations confirmed the infectious origin of the affection without infectious agent in bacteriologic findings. Hence, antibiotic therapy based on oxacillin at a daily dose of $1500 \mathrm{mg}$ per os was continued for three weeks. During one-year follow up, no complications were reported. The aspect of hand is normal; the second finger regained $260^{\circ}$ of the total range of motion without deformity and abnormalities. The last $x$-ray showed bone reconstruction with fibrosis of the ulnar part of the metaphysis (Figure 4).

\section{DISCUSSION}

Subacute metacarpal osteomyelitis in children is a rare disease (1). A few published cases refer to the acute form $(2,3)$.
Although primary acute hematogenous osteomyelitis in childhood is commonly localized in the metaphysis of long bone, the subacute form does not have the same characteristics and can affect diaphyses (4). The most affected metaphysis in subacute osteomyelitis is the tibia (4). Metaphyseal localization in hand bones is possible but has never been described. Several studies showed that subacute osteomyelitis occurred when there was a decreased bacterial virulence and an increased host resistance (5-7). Moreover, early antibiotic therapy in the acute form seems to as a rule result in the occurrence of subacute form since it decreases the virulence of infectious agents $(4,5)$. Subacute metacarpal osteomyelitis may occur in metaphysis but also in both diaphysis and epiphysis, and can be described in radiological findings according to Roberts' classification (7). The main difficulty in the management of subacute metacarpal osteomyelitis is making the diagnosis (8). In this form, physical examination does not reveal abnormalities and a little reduction of motion and mild pain are often seen without any systemic manifestations, so that the infectious origin is usually missed at first examination $(7,8)$. In spite of the benign nature of this affection, other benign and malignant disorders must be considered on differential diagnosis, including eosinophilic granuloma, osteoid osteoma, chondroblastoma, tuberculosis, fungal infection, osteosarcoma, Ewing's sarcoma, leukemia and round cell tumors (9-11). Actually, 


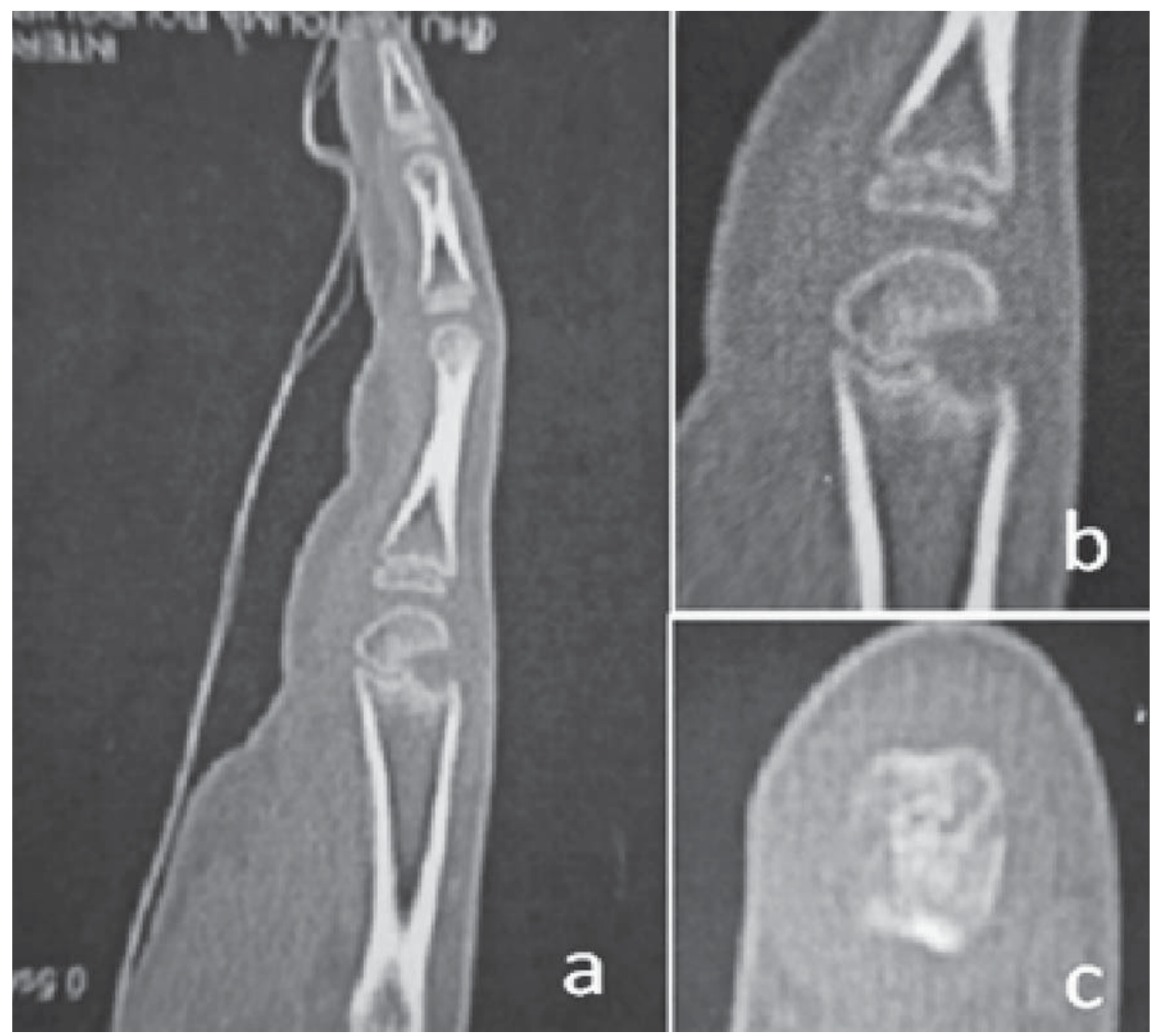

FIGURE 3. Tomography scan of the finger: $(a, b)$ sagittal views of the finger showing the bone defect; $(b)$ transverse axial view revealing the defect on the radial part of the metaphysis.

studies of subacute osteomylitis have demonstrated the value of magnetic resonance imaging (MRI) in diagnosing osteomyelitis in children, also pointing to gadolinium-enhanced imaging as the most sensitive one $(4,12,13)$. MRI exploration helps localize the affection of the bone and provide an objective view of the lesion extent $(10,14)$. However, $x$-rays may underestimate bone destruction and remain normal until the irreversible progression of the infection occurs $(15,16)$.

Treatment of this affection is controversial (17). The recommended treatment for subacute osteomyelitis with a lucent lesion or nidus has been curettage, biopsy and culture, followed by immobilization and antibiotics $(7,10,17)$. In diaphyseal lesions with periosteal reaction, a core of the bone should be taken which includes periosteum, cortex and medullary contents (18). The diagnosis is usually confirmed by histologic examination, which shows an inflammatory component with scattered lymphocytes, plasma cells and granulation tissue $(11,17,18)$. Staphylococcus aureus is regarded as the causative agent by most authors. It is, however, difficult to identify (17-19). Several studies have concluded that antibiotics alone may be adequate and surgery should be reserved for 'aggressive lesions' and those that do not respond to antibiotics $(18,19)$. Cloxacillin is the antibiotic of choice in the treatment of subacute osteomyelitis and is given orally for six weeks after an initial intravenous course for up to five days (19). Subacute metaphyseal osteomyelitis has been shown to disturb the growth plate and compromise the joint $(19,20)$.

In our case, subacute osteomyelitis of metacarpal bone had a satisfactory functional and radiologic outcome comparing to other forms of infectious bone diseases. Antibiotic therapy indicated for five weeks with only two weeks of intravenous treatment seems to be adequate and curative.

It is important to re-emphasize that the subacute form is a clinical entity which is distinct from the acute form and 

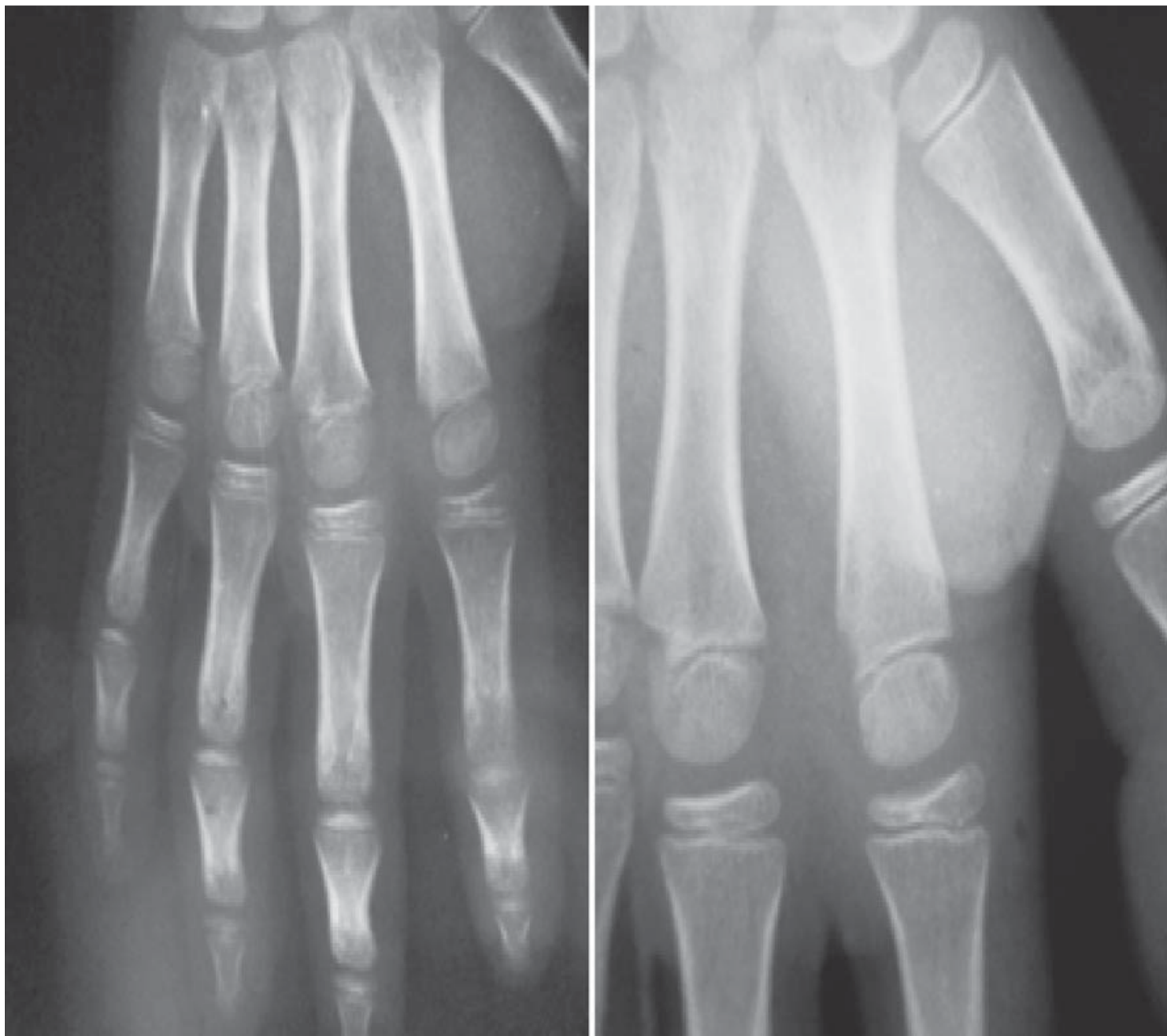

FIGURE 4. The last $\mathrm{x}$-ray of the right hand obtained after one year of surgical debridement with bone reconstruction and mild fibrosis at the infection site.

from those types in which clinical presentation has been modified by the administration of antibiotics. These lesions are frequently confused with a variety of benign and malignant bone tumors and non-pyogenic infections.

\section{NOVČANA POTPORA/FUNDING}

Nema/None

\section{ETIČKO ODOBRENJE/ETHICAL APPROVAL}

Nije potrebno/None

\section{SUKOB INTERESA/CONFLICT OF INTEREST}

Autori su popunili the Unified Competing Interest form na www.icmje.org/ coi_disclosure.pdf (dostupno na zahtjev) obrazac i izjavljuju: nemaju potporu niti jedne organizacije za objavljeni rad; nemaju financijsku potporu niti jedne organizacije koja bi mogla imati interes za objavu ovog rada u posljednje 3 godine; nemaju drugih veza ili aktivnosti koje bi mogle utjecati na objavljeni rad./All authors have completed the Unified Competing Interest form at www.icmje.org/coi_disclosure.pdf (available on request from the corresponding author) and declare: no support from any organization for the submitted work; no financial relationships with any organizations that might have an interest in the submitted work in the previous 3 years; no other relationships or activities that could appear to have influenced the submitted work.

\section{REFERENCES}

1. Rasool MN. Primary subacute haematogenous osteomyelitis in children. $J$ Bone Joint Surg [Br]. 2001;83-B:93-8.doi :10.1302/0301-620X83B1.11180

2. Keret $D$, Giladi $M$, Kletter $Y$, Wientroub S. Cat-scratch disease osteomyelitis from a dog scratch. J Bone Joint Surg [Br]. 1998;80:766-7. doi: 10.1302/0301-620X.80B5.8823.

3. Aebi C, Romilo O. Metacarpalosteomyelitis complicating varicellaassociated cellulitis of the hand: report of 2 cases. Scand J Infect Dis. 1998;30:306-8. doi:10.1080/00365549850161007

4. Hempfing A, Placzek R, Gottsche T, Meiss AL. Primary subacute epiphyseal and metaphyseal osteomyelitis in children. Diagnosis and treatment guided by MRI. J Bone Joint Surg [Br]. 2003;85-B:559-64. doi:10.1302/0301-620X.85B4.13841

5. Mhuircheartaigh JN, Lin YC, Wu JS. Bone tumor mimickers: A pictorial essay. Indian J Radiol Imaging. 2014;24:225-36 doi: 10.4103/0971-3026.137026.

6. Shekhar A, Korlhalli S, Murgod G. Ewing's sarcoma of proximal phalanx of the hand with skip metastases to metacarpals. Indian J Orthop. 2015;49:365-8. doi: 10.4103/0019-5413.156229.

7. Ezra E, Wientroub S. Primary subacute haematogenous osteomyelitis of the tarsal bones in children. J Bone Joint Surg Br. 1997;79:983-6. doi: 10.1302/0301-620X.79B6.7947 
8. Macnicol M. Patterns of musculoskeletal infection in childhood. J Bone Surg [Br]. 2001;83-B:1-2. doi: 10.1302/0301-620X.83B1.11892

9. Cottias $P$, Tomeno B, Anract $P$, Vinh TS, Forest M. Subacute osteomyelitis presenting as a bone tumour; A review of 21 cases. Int Orthop. 1997;21:243-8. doi: 10.1007/s002640050159

10. Calhoun JH, Manring MM, Shirtliff M. Osteomyelitis of the long bones. Semin Plast Surg. 2009;23:59-72. doi: 10.1055/s-0029-1214158

11. Chow LT, Wong SK. Primary osseous inflammatory malignant fibrous histiocytoma masquerading as chronic osteomyelitis. Orthopedics. 2014;37:e940-5. doi: 10.3928/01477447-20140924-92.

12. Merlini L, Anooshiravani M, Ceroni D. Concomitant septic arthritis and osteomyelitis of the hip in young children; a new pathophysiological hypothesis suggested by MRI enhancement pattern. BMC Med Imaging 2015;15:17. doi: 10.1186/s12880-015-0057-0.

13. von Kalle T, Heim N, Hospach T, Langendörfer M, Winkler P, Stuber T. Typical patterns of bone involvement in whole-body MRI of patients with chronic recurrent multifocalosteomyelitis (CRMO). Rofo. 2013;185:655-61. doi: 10.1055/s-0033-1335283.

14. Howe BM, Wenger DE, Mandrekar J, Collins MS. T1-weighted MRI imaging features of pathologically proven non-pedal osteomyelitis. Acad Radiol. 2013;20:108-14. doi.org/10.1016/j.acra.2012.07.015.
15. Godley DR. Managing musculoskeletal infections in children in the era of increasing bacterial resistance. JAAPA. 2015;28:24-9. doi: 10.1097/01.JAA.0000462053.55506.2c.

16. Bires AM, Kerr B, George L. Osteomyelitis: an overview of imaging modalities. Crit Care Nurs Q. 2015;38:154-64. doi: 10.1097/CNQ.0000000000000056.

17. Ceroni D, Belaieff W, Cherkaoui A. Primary epiphyseal or apophyseal subacute osteomyelitis in the pediatric population: a report of fourteen cases and a systematic review of the literature. J Bone Joint Surg Am. 2014;96:1570-5. doi: 10.2106/JBJS.M.00791.

18. Dartnell J, Ramachandran M, Katchburian M. Haematogenous acute and subacute paediatric osteomyelitis: a systematic review of the literature. J Bone Joint Surg Br. 2012;94:584-95. doi: 10.1302/0301-620X.94B5.28523.

19. Shah TT, Chin KF, Noorani A, Nairn D. Subacute physeal abscess: case report to illustrate treatment with a minimally invasive incision and drainage technique. Ann R Coll Surg Engl. 2012;94:e51-4. doi: 10.1308/003588412X13171221502022.

20. Lietzau M, Rehage J, Heppelmann M. Therapeutic procedure of a complicated septic epiphyseal osteomyelitis in a heifer. A case report. Tierarztl Prax Ausg G Grosstiere Nutztiere. 2015;43. doi.org/10.15653/TPG-14099821.

\title{
Subakutni metakarpalni osteomijelitis u djeteta
}

\author{
H. Kaziz, T. Mouelhi, W. Osman, MA. Triki, N. Naouar, ML. Ben Ayeche
}

Subakutni osteomijelitis je rijetka bolest. Kliničke manifestacije su često nejasne i mogu odužiti postavljanje dijagnoze. Zapravo, subakutni metakarpalni osteomijelitis obično se isprva ne prepoznaje pa može doći do komplikacija kao što je brahimetakarpija ili gubitak pokreta. Opisuje se slučaj 10-godišnjeg dječaka sa subakutnim metafizealnim osteomijelitisom druge desne metakarpalne kosti. Radiološke značajke mogu oponašati razne dobroćudne ili zloćudne koštane tumore i ne-piogene infekcije. Neophodna je histološka potvrda kako bi se izbjeglo kašnjenje dijagnoze. Liječenje je provedeno antibioticima i kirurškim debridemanom. Nikakav infektivni uzročnik nije otkriven bakteriološkim pretragama. Na kontrolnom pregledu nakon jedne godine nisu zabilježene nikakve komplikacije, uz normalnu pokretljivost prsta. Rendgenske snimke pokazale su rekonstrukciju kosti s fibrozom ulnarnog dijela metafize bez nesrazmjera u duljini.

Ključne riječi: subakutni; metakarpalni; osteomijelitis; liječenje; komplikacije 